\title{
Editorial: Public Benefit
}

Charity Law in Britain is becoming more stringently regulated like so much else in the public sphere. Educational charities, of which the Royal Institute of Philosophy is an example, are currently being subjected to a 'public benefit' test. That is to say, in order to receive the benefits, reputational and financial, of being a charity, schools and other educational institutions will have to demonstrate that they are providing not just a service to their members, but also a 'public benefit'.

This test is proving irksome in its application to independent schools and the whole issue is now mired in political wrangling. It is not our intention to comment on the minutiae of the arguments involved, or indeed on the rights and wrongs of independent schools maintaining charitable status.

What is worthy of comment here, though, is the more general notion of public benefit. One way of interpreting this notion is that familiar to those applying for grants from government sources and from many charities, where the first question to answer is invariably 'Which section of the community will your work most directly benefit?' The implication is clearly that the more sections of society your work will benefit and probably the more 'disadvantaged' they are, the better your chance of receiving funding.

However there is another and significantly different way of thinking about these matters. It was suggested as long ago as 1531, by Sir Thomas Elyot in The Boke Named the Gouemour: 'Hit semeth that men haue ben longe abused in calling Rempublican a commune weale... there may appere lyke diuersitie to be in Englisshe between a publike weale and a commune weale, as shulde be in latin, between Res publica \& Res plebeia.'

The government's understanding of public benefit clearly leans in the direction of res plebeia. Maybe in a populist democracy one should not be surprised at this. But there clearly are institutions in Britain whose understanding of public benefit is in terms of res publica, and is consistent with a frankly élitist interpretation of their role. The belief is that a society in which such things can flourish is by that very fact a better one to be a part of whether particular individuals or social groups make use of what those institutions have to offer or not. One thinks here of the British Museum, the National Gallery, and, in their 'the best for the most' days at least, the BBC 


\section{Editorial}

and the Arts Council. We hope that institutions of this sort will continue to flourish as charities or as publicly funded bodies without being forced to subscribe to the plebeian interpretation of public benefit. 